Volume 13

Issue 2 Rethinking Genocide, Mass Atrocities,

and Political Violence in Africa: New Directions,

Article 13

New Inquiries, and Global Perspectives

6-2019

\title{
Book Review: Making Ubumwe: Power, State and Camps in Rwanda's Unity-Building Projects
}

Claudine A. Kuradusenge-McLeod

George Washington University

Follow this and additional works at: https://digitalcommons.usf.edu/gsp

\section{Recommended Citation}

Kuradusenge-McLeod, Claudine A. (2019) "Book Review: Making Ubumwe: Power, State and Camps in Rwanda's Unity-Building Projects," Genocide Studies and Prevention: An International Journal: Vol. 13: Iss.

2: $148-149$.

DOI:

https://doi.org/10.5038/1911-9933.13.2.1657

Available at: https://digitalcommons.usf.edu/gsp/vol13/iss2/13

This Book Review is brought to you for free and open access by the Open Access Journals at Digital Commons @ University of South Florida. It has been accepted for inclusion in Genocide Studies and Prevention: An International Journal by an authorized editor of Digital Commons @ University of South Florida. For more information, please contact digitalcommons@usf.edu. 


\section{Book Review: Making Ubumwe: Power, State and Camps in Rwanda's Unity-Building Project}

Claudine Kuradusenge-McLeod

George Washington University

Washington, DC, USA

Making Ubumwe: Power, State and Camps in Rwanda's Unity-Building Project

Andrea Purdeková

Oxford, Berghahn Books, 2015

292 Pages; Price: \$34.95 Paperback

Reviewed by Claudine Kuradusenge-McLeod

George Washington University

Andrea Purdeková offers a brilliant and unique analysis of the social and political tensions existing in Rwanda. Based on ethnographic field work conducted in 2008, Making Ubumwe explores the state sponsored idea of building "a social togetherness and cohesive social whole after genocide."1 By looking at both the Ingando, governmental-sponsored and engineered reeducation camps, and the National Unity and Reconciliation Commission (NURC), she brings to light the social control mechanisms used by the Rwandan government against its population while demonstrating how President Kagame's regime has been able to utilize international support for initiatives promoting unity, reconciliation, and justice. In post-1994, Rwandan took several steps toward not only creating a Rwandanness, which implied all Rwandans (Hutu, Tutsi, and Twa) were one, but also educating foreigners and returnees in order for them to understand and, indirectly, adhere to government controlled-narratives of Rwandan unity and reconciliation. In her own words, "Coexistence and unity among Rwandans are being narrated, implemented and overseen by a narrow elite presiding over an authoritarian regime." ${ }^{2}$

Divided into four sections, Making Ubumwe, takes its readers on a journey of rediscovery, through the eyes of Rwandans citizens, Rwandan Patriot Front (RPF) members, and governmental policies. We are able to look beyond what we know and actually understand the success and progress made since 1994 as well as acknowledge the shortcomings and systems of oppression and the silencing of voices, many books about Rwanda. She is exploring how unity has been conceptualized and institutionalized in today's Rwanda. From how the government promotes it through activities, to how everyday Rwandans understand and talk about it, we learn that unity and reconciliation are seen through performance and silence. The participatory, yet mandatory, events organized by the government have forced the population to have one voice, a voice that promotes government approved scripts. ${ }^{3}$ In other words, public silence is structured and facilitated by the government, which holds tight control over the media, debates, platforms, and activities. ${ }^{4}$

In Rwanda, Ubumwe or building unity is politics. "Unity is a securitized concept overlaid with the notion of friend versus enemy. Unity is defined as 'against an enemy;' unity means being on the 'right side. ${ }^{5}$ This idea of unity implies people become one with the political regime. Those who do not conform are then seen as the enemy. Therefore, in order to promote Ubumwe and assure all Rwandans are 'on the right side,' the Rwandan government created the NURC, which is in charge of organizing 'unity and reconciliation' activities. These activities promote "national building, patriotism, or being together' as mutuality, exchange and sharing..." ${ }^{6}$ Unfortunately, these activities are governmental tools that promote a single-narrative of what Rwanda and Rwandans

\footnotetext{
${ }^{1}$ Andrea Purdeková, Making Ubumwe: Power, State and Camps in Rwanda's Unity-Building Projects (Oxford, Berghahn Books, 2015), 3.

${ }^{2}$ Ibid., 199.

${ }^{3}$ Ibid., 159 .

${ }^{4}$ Ibid., 49.

${ }^{5}$ Ibid., 85.

${ }^{6}$ Ibid., 158.
}

Claudine Kuradusenge-McLeod. "Book Review: Power, State and Camps in Rwanda's Unity-Building Project" 13, 2 (2019): 148-149. 
are. This is also seen through identity politics or the de-ethnicization ideology present in today's Rwanda. In order to promote oneness or a unity policy, the government needed to convince people a common Rwandanness meant omitting or suppressing ethnicity from public or political life. Yet, "ethnicity continues to matter on the ground in Rwanda in terms of how politics is interpreted, and it matters to many of those who try to 'read' Rwandan politics from the outside." ${ }^{7}$ In other words, although the government is promoting unity by all means, Rwandans are still very much divided, often due to the government's attempts to rule with an iron fist. Consequently, the idea of unity is a form of propaganda aimed at uniting people behind the RPF ideology of post-genocide Rwanda.

The initiative Purdeková spent time exploring is the Ingando, which are re-education camps. She offers an in-depth analysis of the history and structure of these camps as well as the social and political aspects used to create unity and reconciliation in the post-genocide Rwanda. These camps are referred to by many names depending on who is attending them. Officially, they are referred to as either "peace and leadership camps, 'solidarity camps,' 'civic education camps' or 'reintegration camps.' Various rumors constitute Ingando either as 'military training,' 'making everyone Tutsi."' 8 Following a strict schedule, these camps are meant to create obedient, almost brainwashed, new citizens. Although the Rwandan government claims they can be traced back to pre-colonial Rwanda, these camps were created by the RPF to mobilize support. ${ }^{9}$ Throughout its history and still today, "ingando are ultimately about the reproduction of political power." ${ }^{10}$

Consequently, this book highlights the different ways in which the Rwandan government has attempted to promote unity and reconciliation as well as some of the motives behind initiatives such as ingando. Purdeková's book seems to have been written for the outside world, for people who have accepted the official narratives of Rwanda and have, consequently, misunderstood the Rwandan conception of the post-genocide reconciliation process. As she explains, "the Rwandan government tries to carefully manage what outside visitors learn about Rwanda; the attempt is to shape access and replicate the opinion of those in power as fact. To spread the appropriate versions of "each and every thing." 11 Those working on issues related to Rwanda, justice, and reconciliation have understood the path President Kagame and his government have taken is a path of authoritarian social control. Due to this, true reconciliation has yet to come. The Rwandan idea of unity and reconciliation has given the government even more power. ${ }^{12}$

In conclusion, Purdeková demonstrated that Rwanda has been able to hide its shortcomings through its policy of unity and reconciliation by projecting a positive image of its post-conflict society, which has allowed the government to manipulate the conceptualization and framing of ubunyarwanda or Rwandanicity. Purdeková successfully offers a deep analysis of this imposed unity and reconciliation promoted by the Rwandan government. Based on her work, she encourages other researchers to focus on the role states and governments play in drafting and implementing interventions. This book is important because it opens up a much needed discussion by not focusing on policy, but rather on how post-conflict initiatives are created and their impact on populations. This conversation offers many lenses and encourages more research. Irrespective of the the discipline, whether it be peace and justice studies, international affairs, political science, or African studies, Purdeková's research offers important food for thought.

\footnotetext{
${ }^{7}$ Ibid., 83.

${ }^{8}$ Ibid., 176.

${ }^{9}$ Ibid., 179.

${ }^{10}$ Ibid., 23.

${ }^{11}$ Ibid., 46.

${ }^{12}$ Ibid., 245-246.
} 